\title{
Phenotypic characterization and 16S rDNA identification of culturable non-obligate halophilic bacterial communities from a hypersaline lake, La Sal del Rey, in extreme South Texas (USA)
}

Kristen Phillips ${ }^{1,2}$, Frederic Zaidan $\|^{2}$, Omar R Elizondo ${ }^{2}$ and Kristine L Lowe $2^{2^{*}}$

\begin{abstract}
Background: La Sal del Rey ("the King's Salt") is one of several naturally-occurring salt lakes in Hidalgo County, Texas and is part of the Lower Rio Grande Valley National Wildlife Refuge. The research objective was to isolate and characterize halophilic microorganisms from La Sal del Rey. Water samples were collected from the lake and a small creek that feeds into the lake. Soil samples were collected from land adjacent to the water sample locations. Sample salinity was determined using a refractometer. Samples were diluted and cultured on a synthetic saline medium to grow halophilic bacteria. The density of halophiles was estimated by viable plate counts. A collection of isolates was selected, gram-stained, tested for catalase, and characterized using API $20 E^{\circledR}$ test strips. Isolates were putatively identified by sequencing the $16 \mathrm{~S}$ rDNA. Carbon source utilization by the microbial community from each sample site was examined using EcoPlate ${ }^{\mathrm{TM}}$ assays and the carbon utilization total activity of the community was determined.
\end{abstract}

Results: Results showed that salinity ranged from 4 parts per thousand (ppt) at the lake water source to 420 ppt in water samples taken just along the lake shore. The density of halophilic bacteria in water samples ranged from 1.2 $\times 10^{2}-5.2 \times 10^{3}$ colony forming units per $\mathrm{ml}^{\left(\mathrm{cfu} \mathrm{ml}^{-1}\right)}$ ) whereas the density in soil samples ranged from $4.0 \times 10^{5}$ $-2.5 \times 10^{6}$ colony forming units per gram $\left(\mathrm{cfu} \mathrm{g}^{-1}\right)$. In general, as salinity increased the density of the bacterial community decreased. Microbial communities from water and soil samples were able to utilize 12 - 31 carbon substrates. The greatest number of substrates utilized was by water-borne communities compared to soil-based communities, especially at lower salinities. The majority of bacteria isolated were gram-negative, catalase-positive, rods. Biochemical profiles constructed from API $20 E^{\circledR}$ test strips showed that bacterial isolates from low-salinity water samples (4 ppt) showed the greatest phenotypic diversity with regards to the types and number of positive tests from the strip. Isolates taken from water samples at the highest salinity (420 ppt) tended to be less diverse and have only a limited number of positive tests. Sequencing of 16S DNA displayed the presence of members of bacterial genera Bacillus, Halomonas, Pseudomonas, Exiguobacterium and others. The genus Bacillus was most commonly identified. None of the isolates were members of the Archaea probably due to dilution of salts in the samples.

Conclusions: The La Sal del Rey ecosystem supports a robust and diverse bacterial community despite the high salinity of the lake and soil. However, salinity does appear to a limiting factor with regards to the density and diversity of the bacterial communities that inhabit the lake and surrounding area.

\footnotetext{
* Correspondence: klowe@utpa.edu

${ }^{2}$ Department of Biology, University of Texas - Pan American, Edinburg, Texas USA

Full list of author information is available at the end of the article
} 


\section{Background}

Halophilic microorganisms have been isolated from many environments such as salterns [1], cold seeps [2], fish sauce [3], salt mines [4], brine wells [5] and salt lakes [6-8], including lakes in Antarctica [9] (for reviews, see $[10,11])$. Halophily is observed in members of the Bacteria, Archaea, and Eukarya [10] and there is diversity amongst halophiles with regards to the concentration of salts, temperatures, $\mathrm{pH}$ conditions, and redox conditions that the organisms are adapted. Thermophilic, psychrophilic, mesophilic, alkaliphilic, and aerobic halophiles have been described $[12,13]$, as well as anaerobic halophilic bacteria capable of denitrification and sulfate reduction [14]. Halophiles play a role in the biogeochemistry of carbon and phosphorus in saline environments [15] and some halophiles have been shown to degrade organic compounds, such as pesticides and crude oil [16-19], for potential use in bioremediation studies and applications. In addition to bioremediation, halophiles may also have potential uses as biocontrol agents against certain pathogenic fungi $[20,21]$.

A high saline environment places osmotic stress on living cells making them vulnerable to dehydration. Moreover, cellular proteins, including enzymes, may denature (unfold) at high salt concentrations leading to decreased enzyme activity and DNA damage [11]. Halophiles employ different morphological, physiological, and genetic mechanisms to withstand the environmental conditions in which they live. These include increasing internal cellular concentrations of solutes such as potassium ions $(\mathrm{K}+)$ or amino acid derivatives [10], having cell walls that are stabilized by sodium ions $(\mathrm{Na}+)$, and having extra copies of essential genes located on large plasmids [11]. Redundant genes may allow for the rapid repair of DNA that may become damaged due to high salinity; gene redundancy and rapid DNA repair is observed in other bacteria that inhabit environments, such as arid and desiccated environments, that can cause DNA damage. Such bacteria excise damaged DNA and use non-damaged areas as templates for repair [[22] and references therein].

Halotolerant and halophilic organisms are able to efficiently exclude sodium ions from the cell interior. Eukaryotic halophiles have been shown to possess ATPdriven $\mathrm{Na}+$ pumps which actively remove the ions from the cell [23]. In bacteria, sodium removal is accomplished by sodium-proton exchange via $\mathrm{Na}+/ \mathrm{H}+$ antiports [24].

Many halophiles build up concentrations of compatible solutes in their cytoplasm to combat the osmotic pressure exerted by the environment. This can be accomplished by either pumping inorganic ions into the cell from the environment or by synthesizing or concentrating an organic solute [11]. Low molecular weight organic molecules such as glycerol, sugars, glutamate, proline, and ectoine are examples of compatible solutes [11]. Glycine betaine, a methylated glycine deriviative, is widely used by halophilic bacteria as a compatible solute [11].

La Sal del Rey ("the King's Salt") is one of several naturally-occurring salt lakes in Hidalgo County, Texas, USA and is part of the Lower Rio Grande Valley National Wildlife Refuge [25]. The geological source of the salt in La Sal del Rey is unknown but archeological evidence suggests that prehistoric persons, Native American tribes, and Spanish, Mexican and American settlers mined salt from the lake for use in food preservation and mineral trade [26,27]. A diversity of wildlife species live near the lake, including mammals, birds, reptiles, amphibians, arachnids and insects. A recent phylogenetic study conducted by Hollister et al. [28] showed that the microbial community of La Sal del Rey is diverse and is represented by at least 24 bacterial and 2 archaeal phyla. However, that study relied solely on non-culture methods such as $16 \mathrm{~S}$ rDNA sequencing and quantitative (Q)-PCR, and sampled soils and sediments along a transect leading up to the lake shore. As a complement to that study, we isolated potential prokaryotic halophiles from water in La Sal del Rey and soils at the lake shore. We characterized the microorganisms using traditional morphological, physiological, and phenotypic techniques along with $16 \mathrm{~S}$ rDNA identification and compared organisms isolated from different regions of the La Sal del Rey that had disparate salinities.

\section{Methods}

\section{Sample Collection and Site Characteristics}

Water samples (5) and soil samples (3) were collected from locations in the La Sal del Rey area $\left(26^{\circ} 31^{\prime} 55^{\prime \prime} \mathrm{N}\right.$, $98^{\circ} 03^{\prime} 50^{\prime \prime}$ W; Figure 1). Sites A - F samples were taken on 14 June 2010; sites G - H samples were taken on 5

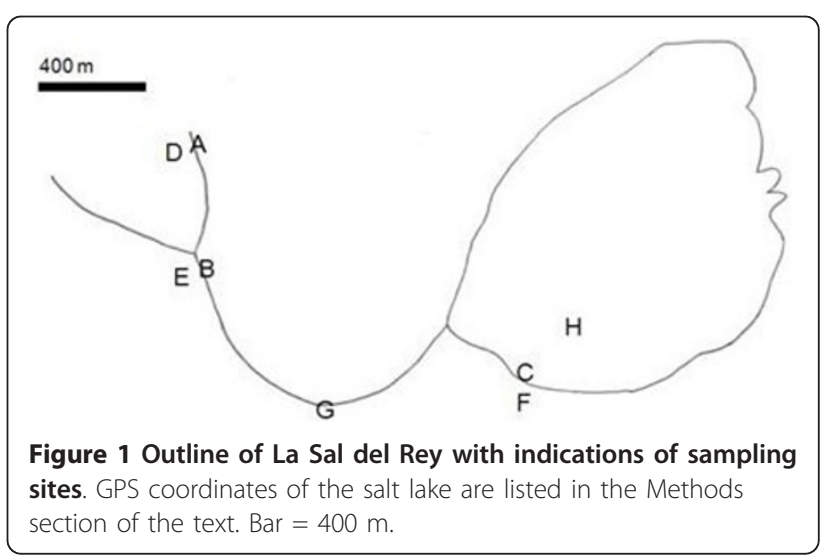


July 2010. Samples from A (water) and D (soil) were taken near the La Sal del Rey source water. Samples from B (water) and E (soil) were taken approximately $400 \mathrm{~m}$ south of the source. Samples from C (water) and F (soil) were taken at the lake shore, approximately 800 $\mathrm{m}$ east of sites B and E. Water was also collected from site $\mathrm{G}$ located mid-way between the water source and the lake and from within the lake (site $\mathrm{H}$ ) after a major storm event, Hurricane Alex. Prior to the hurricane, the lake water level was visibly lower and the salinity of the water was higher.

Water samples were obtained by fully submersing a clean, sterile $50-\mathrm{mL}$ plastic tube underneath the water surface. The lid was removed when the tube was $10-\mathrm{cm}$ below the water surface to ensure that air was not introduced into the sample. The lid was replaced while submerged and the tube was appropriately labeled and dated. Soil samples were taken from the upper $10 \mathrm{~cm}$ using a small shovel and transferred to sterile containers. The samples were transported to the lab on ice and processed within $24 \mathrm{~h}$ of collection. Salinity of the water samples was measured using a model REF211ATC handheld refractometer (General Tools and Instruments, New York NY). Salinity of the soil samples was estimated by extracting porewater from the soil and measuring salinity using the handheld refractometer.

\section{Sample culturing}

Serial dilutions $\left(10^{0}, 10^{-1}, 10^{-2}\right.$, and $\left.10^{-3}\right)$ of water and soil samples were made in sterile saline $(0.85 \%)$. A 100 $\mu \mathrm{L}$ aliquot of each diluted sample was spread onto a saline media. The contents of the media per liter were peptone $(5 \mathrm{~g})$, yeast extract $(1 \mathrm{~g})$, ferric citrate $(0.1 \mathrm{~g}), \mathrm{NaCl}$ (19.45 g), $\mathrm{MgCl}_{2}$ (8.8 g), $\mathrm{Na}_{2} \mathrm{SO}_{4}$ (3.24 g), $\mathrm{CaCl}_{2}$ (1.8 g), $\mathrm{KCl}(0.55 \mathrm{~g}), \mathrm{NaHCO}_{3}(0.16 \mathrm{~g}), \mathrm{KBr}(0.08 \mathrm{~g}), \mathrm{SrCl}_{2}(34.0$ $\mathrm{mg}$ ), $\mathrm{BH}_{3} \mathrm{O}_{3}$ (22.0 mg), $\mathrm{Na}_{2} \mathrm{SiO}_{3}(4.0 \mathrm{mg}), \mathrm{NaF}$ (2.4 mg), $\mathrm{NH}_{4} \mathrm{NO}_{3}(1.6 \mathrm{mg}), \mathrm{Na}_{2} \mathrm{HPO}_{4}(8.0 \mathrm{mg})$ and agar $(15.0 \mathrm{~g})$. Samples were plated in triplicate and incubated at $25^{\circ} \mathrm{C}$ for $7 \mathrm{~d}$. Colonies growing on the plates were counted and the density of microorganisms in the original sample was estimated by multiplying the colony count times the dilution.

\section{Community Nutrient Profile}

Water and soil samples collected were tested using BIOLOG EcoPlates ${ }^{\mathrm{TM}}$ (BIOLOG Inc., Hayward CA), which determine the types of carbon substrates that microbial communities can use. EcoPlates ${ }^{\mathrm{TM}}$ are 96-well microplates containing 31 different carbon sources in triplicate with a dye and 3 water (control) wells. The following carbon substrates were available on EcoPlates $^{\mathrm{TM}}$ : $\beta$-Methyl-D-glucoside, D-Galactonic Acid $\gamma$ Lactone, L-Arginine, Pyruvic Acid Methyl Ester, DXylose, D-Galacturonic Acid, L-Asparagine, Tween 40,
i-Erythritol, 2-Hydroxy Benzoic Acid, L-Phenylalanine, Tween 80, D-Mannitol, 4-Hydroxy Benzoic Acid, L-Serine, $\alpha$-Cyclodextrin, N-Acetyl-D-Glucosamine, $\gamma$-Hydroxybutyric Acid, L-Threonine, Glycogen, D-Glucosaminic Acid, Itaconic Acid, L-Glutamic Acid, D-Cellobiose, Glucose-1-Phosphate, $\alpha$-Ketobutyric Acid, Phenylethylamine, $\alpha$-D-Lactose, D, L- $\alpha$-Glycerol Phosphate, D-Malic Acid, and Putrescine. If the microbial community could utilize the carbon source, the microplate well turned purple. The amount of utilization (how well the substrate was used) was proportional to the color intensity. Color intensity was quantified by taking the absorbance at $595 \mathrm{~nm}$ using a microplate reader (BioRad Model 680 , Hercules, CA). Samples were measured in triplicate at $24 \mathrm{~h}, 48 \mathrm{~h}$, and $72 \mathrm{~h}$. The total number of used substrates (substrate richness), the best utilized substrate, and the total activity (equal to the sum of all positive absorbance values) was determined for each sample.

\section{Characterization of Isolates}

Selected colonies grown from 14 June 2010 samples were characterized by gram-stain and by observed cell morphology (i.e., shape) using a light microscope. To obtain a diverse assortment of isolates, colonies were chosen that displayed different color plate morphologies, different colony shape and sizes, and different colony textures (e.g., shriveled, mucoid). Isolates were tested for the presence of the enzyme catalase by aseptically transferring a small amount of cells onto a glass slide and adding 2-3 drops of $3 \% \mathrm{H}_{2} \mathrm{O}_{2}$. The observed production of bubbles was considered a positive test for catalase.

\section{API $20 E^{\circledR}$ strips}

Biochemical profiles for isolates were generated using API 20E ${ }^{\circledR}$ strips (bioMérieux Inc., Durham, NC). API $20 E^{\circledR}$ strips include enzymatic tests for fermentation or oxidation of glucose, mannitol, inositol, sorbitol, rhamnose, saccharose, melibiose, amygdalin, and arabinose, along with nitrate reduction to nitrite and nitrate reduction to nitrogen gas. API $20 \mathrm{E}^{\circledR}$ strips also test for the presence of $\beta$-galactosidase, arginine dihydrolase, lysine decarboxylase, ornithine decarboxylase, citrate utilization, $\mathrm{H}_{2} \mathrm{~S}$ production, urease, tryptophan deaminase, indole production, acetoin production (Voges - Proskauer), and gelatinase. API $20 \mathrm{E}^{\circledR}$ tests were performed according to the manufacturer's instructions. The number and types of positive tests were tabulated for the isolates and used to construct biochemical phenotype profiles of the cultures which were compared amongst the isolates. A similarity dendogram among profiles was constructed using the program NTSYSpc (Exeter Software, Setauket, NY). To construct the similarity dendogram, an input matrix was constructed with the 21 API $20 \mathrm{E}^{\circledR}$ tests. If a bacterial isolate was positive for that 
test, the matrix input was ' 1 '. If the isolate was negative for the test, the matrix input was ' 0 '. The NTSYSpc software was then used according to the manufacturer's instructions to produce a similarity matrix and tree. Each isolate's profile was compared to the profile of all the other isolates and reported as a Coefficient of Similarity on a scale of $0.00-1.00$ with 1.00 equal to $100 \%$ similarity.

\section{Sequencing of 16S DNA}

Pure cultures of bacterial isolates were identified by MIDI Labs (Newark, DE). Identification was made by sequencing approximately the first $500 \mathrm{bp}$ of the $16 \mathrm{~S}$ rRNA gene and comparing the sequences to the $16 \mathrm{~S}$ rRNA data base by BLAST and Needleman Wunsch. Primers used were 005F (5' - TGG AGA GTT TGA TCC TGG CTC AG - 3') and 531R (5' - TAC CGC GGC TGC TGG CAC - 3'). PCR amplification and DNA sequencing was performed using the MicoSeq ${ }^{\circledR}$ $50016 \mathrm{~S}$ rDNA Bacterial Identification Kits according to the manufacturer's protocols (Applied Biosystems, Foster City, CA).

\section{Statistical Analysis}

A two-way ANOVA [29] was used to test the main effects of sample location and substrate type and their interaction on colony forming units, total activity, and number of EcoPlate ${ }^{\mathrm{TM}}$ substrates that were utilized. Significance was evaluated at $\alpha=0.05$ and when necessary, Tukey's Post Hoc tests were used to compare means within a group [30].

\section{Results}

The measured salinity for La Sal del Rey samples (Figure 1) varied from a low of 4 ppt at site A, the water source of the lake, to a high of $420 \mathrm{ppt}$ at site $\mathrm{C}$ just along the shoreline of the lake (Table 1). Samples from sites $\mathrm{G}$ and $\mathrm{H}$ were taken after Hurricane Alex deposited very heavy rainfall to the area, greater than $15 \mathrm{~cm}$ in some locations from 30 June - 2 July 2010 [31]. The salinity at site $H$ was nearly half that measured at site $\mathrm{C}$ before the hurricane (Table 1).

The microbial density was measured by viable plate counts on saline media containing $19.5 \mathrm{~g} \mathrm{~L}^{-1} \mathrm{NaCl}$ and other salts. Density was estimated as the number of colony forming units per $\mathrm{ml}$ or per gram $\left(\mathrm{cfu} \mathrm{ml}^{-1}\right.$ or cfu $\mathrm{g}^{-1}$ ) for water and soil samples, respectively. Microbial density for water samples taken on 14 June 2010 (A C) ranged from $1.2 \times 10^{2}$ to $5.2 \times 10^{3} \mathrm{cfu} \mathrm{ml}^{-1}$. In samples A - C, as salinity increased, the population density of the isolated species decreased (Figure 2). Soil samples taken at the same time, sites D - F, had much higher microbial densities than the water samples. After the hurricane, the cfu $\mathrm{ml}^{-1}$ in water samples was substantially higher than before suggesting that salinity is a controlling factor of microbial density in the ecosystem.

Assays using EcoPlate ${ }^{\mathrm{TM}}$ microplates showed that many carbon sources could be used as substrates by the microbial communities taken from La Sal del Rey samples. The highest number of utilized substrates was observed in the community from sample $G$, which was positive for all 31 carbon sources tested (Table 2). The lowest number of used substrates, 12, was observed in the community in sample E. Each sample's community displayed a different preferred substrate (i.e., the greatest absorbance value) and no single substrate was preferred by all communities. The community from sample A displayed the highest total activity (the sum of all positive absorbance values) and also used a high number of substrates. The environmental conditions at site A are close to freshwater and near the water source for La Sal del

Table 1 Salinity, EcoPlate ${ }^{\mathrm{TM}}$ utilization, and isolate characteristics for samples taken from La Sal del Rey 2010.

\begin{tabular}{ccccccc}
\hline Sample & Salinity $(\mathbf{p p t})$ & $\begin{array}{c}\text { Preferred } \\
\text { EcoPlaterM Substrate* }\end{array}$ & \multicolumn{3}{c}{ Isolates } \\
\cline { 3 - 6 } & & & $\mathbf{N}$ & Gram-negative & Rod-shaped & Percent catalase positive \\
\hline A & 4 & L-phenylalanine & 20 & 15 & 14 & 100 \\
B & 56 & Glycogen & $20^{\dagger}$ & 16 & 16 & 95 \\
C & 420 & Itaconic Acid & 10 & 2 & 9 & 100 \\
D & 4 & Tween 40 & 17 & 14 & 4 & 100 \\
E & 37 & L-arginine & 17 & 15 & 12 & 100 \\
F & 280 & D-cellobiose & 16 & 14 & nd & nd \\
G & 86 & D-malic acid & nd & nd & nd & nd \\
H & 220 & Hydroxybutyric acid & nd & nd & nd & \\
\hline
\end{tabular}

* Highest positive EcoPlate ${ }^{\mathrm{TM}}$ absorbance value

${ }^{+}$One isolate from site B became contaminated and was eliminated from the study.

nd $=$ not determined

Samples A - F were taken on 14 June; samples G - H were taken on 5 July after Hurricane Alex made landfall. Salinity was measured using a handheld refractometer. EcoPlates ${ }^{\mathrm{TM}}$ were inoculated with water or diluted soil samples, incubated at $25^{\circ} \mathrm{C}$, and measured with a spectrophotometer (595 nm) at $24 \mathrm{~h}, 48$ $\mathrm{h}$ and $72 \mathrm{~h}$. EcoPlates ${ }^{\mathrm{TM}}$ results shown are the final results at $72 \mathrm{~h}$. Isolates were selected from amongst all the samples. Some isolates contained a mixture of cell types. 


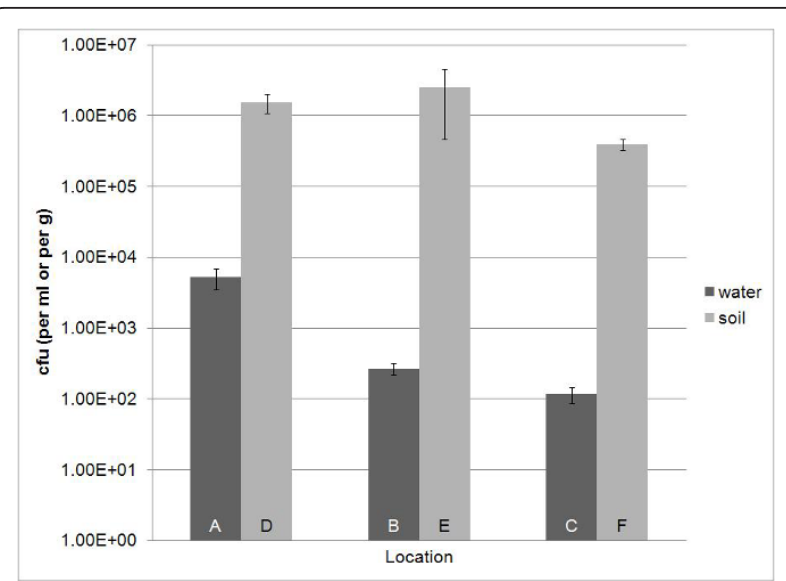

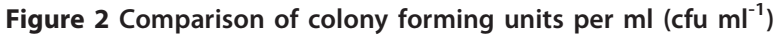
and colony forming units per gram ( $\mathrm{cfu} \mathrm{g}^{-1}$ ) for water samples versus their counterpart soil samples taken on 14 June 2010.

Rey. The total activity was generally lower in soil samples (E - F) compared to water samples (A - C, G, H). Among water samples, the total activity was greatest at site A, decreased at higher salinities and after a hurricane event (samples G, H). Interestingly, although site A had the highest total activity, it did not have the highest microbial density whereas sites D - $\mathrm{H}$ had higher densities of microorganisms but not as high substrate utilization or activity.

Random isolates were selected from agar plates inoculated on 14 June 2010. A total of 100 isolates were chosen and examined for cell morphology and the presence of the enzyme catalase. Most isolates were gram-negative $(76 \%)$ and rod-shaped (71\%) and virtually all were positive for catalase (Table 1). Color morphology of the cultures was typically off-white, orange-red, red, or yellow. Several cultures from site B underwent a series of color changes as the cultures aged. When these isolates were streaked onto fresh medium, the initial color of the colonies was off-white. Within 12 - 18 hours the colonies appeared green and later turned orange or orange-red (Figure 3). Further visual inspection revealed the presence of 2 strains; however, it was difficult to isolate them individually as pure cultures. When the cultures were separated, the growth of one was visibly slower and the other had very little growth. It is possible that the organisms have a symbiotic association that enhances the growth of both.

Cultured isolates $(\mathrm{n}=49)$ from sites $\mathrm{A}, \mathrm{B}$, and $\mathrm{C}$ were screened for biochemical phenotypes using API $20 \mathrm{E}^{\circledR}$ test strips. A suite of 21 tests was used to construct a phenotype profile for each isolate. The number of positive tests displayed by the isolates ranged from 1 to 19 . Many of the isolates that displayed only 1 positive test came from site $C$, which had the highest salinity (data not shown). The phenotype profiles were compared against each other and a similarity dendrogram was constructed. The similarity comparison examined both the number of positive tests and which tests were positive between organisms. Each isolate's phenotype profile was compared against the other 48 isolates' phenotype profiles. The similarity comparison is shown in Figure 4. Overall, all the isolates displayed a minimum similarity coefficient of approximately 0.4 or displayed phenotype profiles that were approximately $40 \%$ similar. The isolates' phenotypes were divided into 2 similarity clusters. A group of 10 bacterial isolates from site $\mathrm{A}$, which contained the lowest salinity, formed 1 group that were $>65 \%$ similar (Figure 4, upper part of figure). A few of the isolates in that cluster showed identical phenotype profiles. Isolates A9 and A10 and isolates A11 and A13 were identical to each other. The other cluster was a mixture of isolates from sites $\mathrm{A}, \mathrm{B}$, and $\mathrm{C}$. The isolates in this group generally had fewer positive tests than those isolates making up the other cluster. Many of the isolates from site $C$, which had the highest salinity, had identical phenotype profiles but this was generally due to those isolates displaying few positive tests. Most of the isolates from site $C$ were only positive for a single test. The site $\mathrm{C}$ organisms were all positive for the Voges-Proskauer test, which is a qualitative test for the production of acetyl methylcarbinol (acetoin) from glucose. The high number and diversity of cultures from site A combined with the low number of positive tests among cultures from site $\mathrm{C}$ suggests that the higher salinity of the environment selects for less diversity in phenotypes. However, the change in diversity was not inversely proportional to the salinity across the entire salinity gradient.

A subset $(n=37)$ of the cultured organisms were presumptively identified by $16 \mathrm{~S}$ rDNA sequencing (Table 3). All isolates were Bacteria; there were no Archaea identified. Isolate D12, although not included in the API assays, showed $95.8 \%$ similarity to Bacillus oleronius. Other isolates (A2, A3, A9, A12, and A16) also had the closest match to $B$. oleronius; however, the matches could not be made to the species level (i.e., a match > 99\%). Furthermore, none of these isolates had identical phenotype API ${ }^{\circledR}$ profiles (Figure 4). Isolates A9 and A16 were approximately $41 \%$ similar to the other isolates and were found in the same cluster on the API ${ }^{\circledR}$ dendogram. Isolates A2, A3, and A12 were located in the other cluster on the dendogram and were approximately $85 \%$ similar with regards to their $\mathrm{API}^{\circledR}$ profiles. The sequence and phenotype data suggests that the organisms are different species or perhaps different strains or biovars of the same species.

All 10 isolates from site $C$, water sampled from the lake shore (salinity $420 \mathrm{ppt}$ ), all showed the highest $16 \mathrm{~S}$ 
Table 2 BIOLOG EcoPlateTM assays of samples from La Sal del Rey.

\begin{tabular}{|c|c|c|c|c|c|c|c|c|}
\hline & & & & Sampl & cation & & & \\
\hline & A & B & $\mathrm{C}$ & D & $\mathrm{E}$ & $\mathrm{F}$ & G & $\mathrm{H}$ \\
\hline \multicolumn{9}{|l|}{ Substrate } \\
\hline$\beta$-Methyl-D-Glucoside & $x$ & $x$ & $x$ & $x$ & & $x$ & $x$ & $x$ \\
\hline D-Galactonic Acid $\gamma$-Lactone & $x$ & $x$ & $x$ & $x$ & & $x$ & $x$ & \\
\hline L-Arginine & $x$ & $x$ & $x$ & $x$ & $x$ & $x$ & $x$ & $x$ \\
\hline Pyruvic Acid Methyl Ester & $x$ & & $x$ & $x$ & & $x$ & $x$ & \\
\hline D-Xylose & $x$ & $x$ & $x$ & $x$ & $x$ & $x$ & $x$ & \\
\hline D-Galacturonic Acid & $x$ & $x$ & $x$ & $x$ & & $x$ & $x$ & \\
\hline L-Asparagine & $x$ & $x$ & $x$ & $x$ & $x$ & $x$ & $x$ & \\
\hline Tween 40 & $x$ & $x$ & $x$ & $x$ & & $x$ & $x$ & $x$ \\
\hline i-Erythritol & $x$ & $x$ & $x$ & & & $x$ & $x$ & \\
\hline 2-Hydroxy Benzoic Acid & & & $x$ & & & & $x$ & $x$ \\
\hline L-Phenylalanine & $x$ & $x$ & $x$ & & & & $x$ & \\
\hline Tween 80 & $x$ & $x$ & $x$ & $x$ & & & $x$ & \\
\hline D-Mannitol & $x$ & $x$ & $x$ & & & $x$ & $x$ & $x$ \\
\hline 4-Hydroxy Benzoic Acid & $x$ & & $x$ & $x$ & & & $x$ & \\
\hline L-Serine & $x$ & $x$ & & $x$ & $x$ & $x$ & $x$ & $x$ \\
\hline$\alpha$-Cyclodextrin & $x$ & $x$ & $x$ & $x$ & & $x$ & $x$ & \\
\hline N-Acetyl-D-Glucosamine & $x$ & $x$ & $x$ & $x$ & & $x$ & $x$ & \\
\hline$\gamma$-Hydroxybutyric Acid & $x$ & $x$ & $x$ & $x$ & $x$ & $x$ & $x$ & $x$ \\
\hline L-Threonine & $x$ & $x$ & & $x$ & $x$ & $x$ & $x$ & \\
\hline Glycogen & $x$ & $x$ & & $x$ & $x$ & $x$ & $x$ & \\
\hline D-Glucosaminic Acid & $x$ & $x$ & $x$ & $x$ & & $x$ & $x$ & $x$ \\
\hline Itaconic Acid & $x$ & $x$ & $x$ & $x$ & & $x$ & $x$ & $x$ \\
\hline Glycyl-L-Glutamic Acid & $x$ & $x$ & $x$ & $x$ & $x$ & $x$ & $x$ & $x$ \\
\hline D-Cellobiose & $x$ & $x$ & $x$ & $x$ & $x$ & $x$ & $x$ & $x$ \\
\hline Glucose-1-Phosphate & $x$ & $x$ & $x$ & $x$ & $x$ & $x$ & $x$ & $x$ \\
\hline$\alpha$-Ketobutyric Acid & $x$ & $x$ & $x$ & $x$ & & $x$ & $x$ & \\
\hline Phenylethylamine & $x$ & $x$ & $x$ & $x$ & $x$ & $x$ & $x$ & $x$ \\
\hline$\alpha$-D-Lactose & $x$ & $x$ & $x$ & $x$ & & $x$ & $x$ & $x$ \\
\hline D, L- $\alpha$-Glycerol Phosphate & $x$ & $x$ & $x$ & $x$ & & $x$ & $x$ & $x$ \\
\hline D-Malic Acid & $x$ & $x$ & $x$ & $x$ & & $x$ & $x$ & $x$ \\
\hline Putrescine & $x$ & $x$ & $x$ & $x$ & $x$ & $x$ & $x$ & \\
\hline Number of Utilized Substrates & 29 & 28 & 28 & 27 & 12 & 27 & 31 & 16 \\
\hline Total Activity & 32.858 & 6.995 & 9.492 & 7.780 & 0.397 & 0.768 & 3.794 & 2.506 \\
\hline
\end{tabular}

An ' $x$ ' indicates that the organic substrate was utilized by the microbial community. Total activity is the sum of positive absorbance values for all utilized substrates.

rDNA match to B. firmus (Table 3). With the exception of isolate $\mathrm{C} 1$, all the cultures from this highly saline site had the same phenotype profile (Figure 4). Isolates A15 and B2, from sites A and B, respectively, also showed the closest match to $B$. firmus. The confidence levels of the matches to $B$. firmus could only be made to the genus level. Sequencing of the $16 \mathrm{~S}$ rDNA also elucidated the presence of several other potential members of the genus Bacillus. These included: B. circulans, B. fastidiosis, B. megaterium, B. thuringiensis, and B. horikoshii (Table 3).

In addition to Bacillus, 4 isolates (A8, A14, A17, and A20) had the closest match to the Exiguobacterium, which along with Bacillus are grouped within the
Firmicutes phylum of low $\mathrm{G}+\mathrm{C}$ gram-positive bacteria. Other matches to the isolates' $16 \mathrm{~S}$ rDNA included several gram-negative organisms such as Vibrio alginolyticus, Pseudomonas fulva, and Planococcus citreus. Organisms A11, A18, and B5 were closely matched to the known halophile species Halomonas aquamarina (Table 3).

Water and soil samples A - F were taken on the same day prior to the hurricane event; therefore, we compared water samples to soil samples with regards to the $\mathrm{cfu} \mathrm{ml}^{-1}$ or $\mathrm{g}^{-1}$, total activity, and number of EcoPlate $^{\mathrm{TM}}$ substrates that were utilized. Samples from sites $G$ and $H$ were not considered in the comparison because only water samples were taken on that day. 


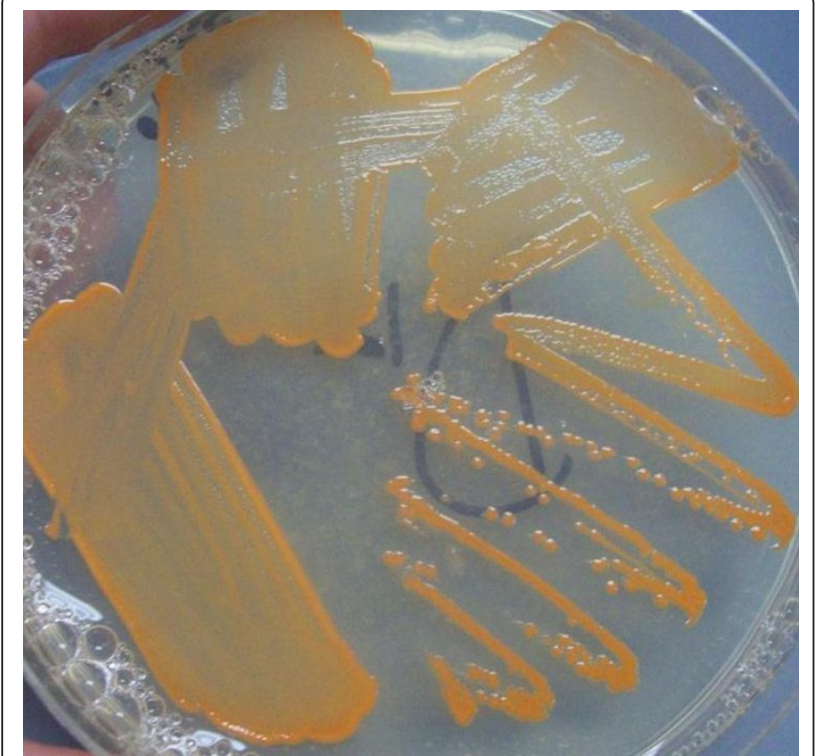

Figure 3 Representative culturable halophile from La Sal del Rey, Texas.

The number of cfu was significantly $\left(\mathrm{F}_{1,12}=13.48, \mathrm{P}=\right.$ 0.0032 ) higher in the soil than in the water samples (Figure 2). The overall model did not detect a significant location effect $\left(\mathrm{F}_{2,12}=2.29, \mathrm{P}=0.1435\right)$, but this was due to the two orders of magnitude difference between the soil and water values. A secondary analysis by substrate type (ANOVA and Tukey's Post Hoc test) revealed significantly higher colony forming units in the freshwater sample than in either of the two saline samples $\left(\mathrm{F}_{2,6}=25.76, \mathrm{P}=0.0011\right)$. No other significant effects were detected (all $\mathrm{P}>0.1437$ ). The amount of total activity was significantly $\left(\mathrm{F}_{1,12}=196.06, \mathrm{P}<\right.$ $0.0001)$ higher in the water than in the soil samples and decreased significantly $\left(\mathrm{F}_{2,12}=121.63, \mathrm{P}<0.0001\right)$ when going from fresh to salt water in both substrate types. In the water samples, total activity decreased from 32.858 in the freshwater to an average of 8.243 once the salinity was above 56 ppt. The same pattern was observed in the soil samples, but with lower activities (7.78) in the freshwater decreasing to an average of 0.583 when salinity was above $37 \mathrm{ppt}$. The number of utilized substrates was significantly $\left(\mathrm{F}_{1,12}=21.17\right.$, P $=0.0006)$ higher in the water than in the soil samples. The water samples utilized 28.33 EcoPlate ${ }^{\mathrm{TM}}$ carbon sources on average whereas the soil samples used an average of 22.0. No other significant effects were detected (all $\mathrm{P}>0.0681$ ).

\section{Discussion}

While the definition of 'halophile' varies, the traditional descriptive scheme divides halophiles into 3 categories: slight halophiles, which grow optimally at low salinities of 20-50 ppt $\mathrm{NaCl}$; moderate halophiles, which grow optimally at salinities of 50-200 ppt $\mathrm{NaCl}$; and extreme halophiles that grow optimally at salinities $>200 \mathrm{ppt}$ $\mathrm{NaCl}$ [11]. The salinity of La Sal del Rey was as high as 420 ppt and soil porewater as high as 280 ppt. However, the medium used for culturing in this study contained only 19.45 ppt $\mathrm{NaCl}$ along with other salts. Despite the relatively low salinity of the medium used, we observed densities of approximately $10^{6} \mathrm{cfu} \mathrm{g}^{-1}$ for soil samples and $10^{7} \mathrm{cfu} \mathrm{ml}{ }^{-1}$ or higher, especially after the passage of Hurricane Alex. The large rainfall amounts from the hurricane resulted in lower salinity of the water and may also have served as an input for nutrients into the lake, both of which may have contributed to growth of bacteria. In samples taken from 14 June 2010, prior to Hurricane Alex, we observed that soil samples contained greater densities of bacteria compared to water samples. Among water samples taken on that date, the greatest community density was observed at the lowest salinity, near the source waters of the lake. This suggests that salinity is a limiting factor in community size at least for culturable bacteria. The increase in community densities observed after the passage of the hurricane, when the salinity declined, would seem to support this. Furthermore, there was a negative correlation between the measured salinity of the sample and the estimated culturable community size.

The high density of bacteria in some samples may have been due to the presence of one or just a small number of species. The viable plate counts, API ${ }^{\circledR}$ phenotype profiles, and the $16 \mathrm{~S}$ rDNA sequencing revealed that the density and diversity of the bacterial community decreased as the salinity increased. For example, the phenotype diversity in site A (with 4 ppt salinity) was much greater than the other sites (Figure 4). Furthermore, the 16S rDNA identities of organisms from this site showed the presence of at least 5 genera and possibly 11 species (Table 2). At Site B (56 ppt), we observed 4 genera and possibly 5 species. However, at site C (420 ppt), the API ${ }^{\circledR}$ phenotypes of the organisms were virtually $100 \%$ identical and the $16 \mathrm{~S}$ rDNA sequencing showed that they were all the same genus and species. Thus, at site $C$ the density of the organisms is most likely due to one or a few number species; at lower salinity sites, the density is greater and contains a more diverse community.

Hollister et al. [28] observed that the community diversity was not well correlated with salinity but rather was dependent on other factors such as soil water content and the amount of organic carbon in the soil. We tested the microbial communities' ability to utilize 31 different organic carbon substrates using EcoPlates ${ }^{\mathrm{TM}}$. The communities could use between 12 - 31 substrates, 


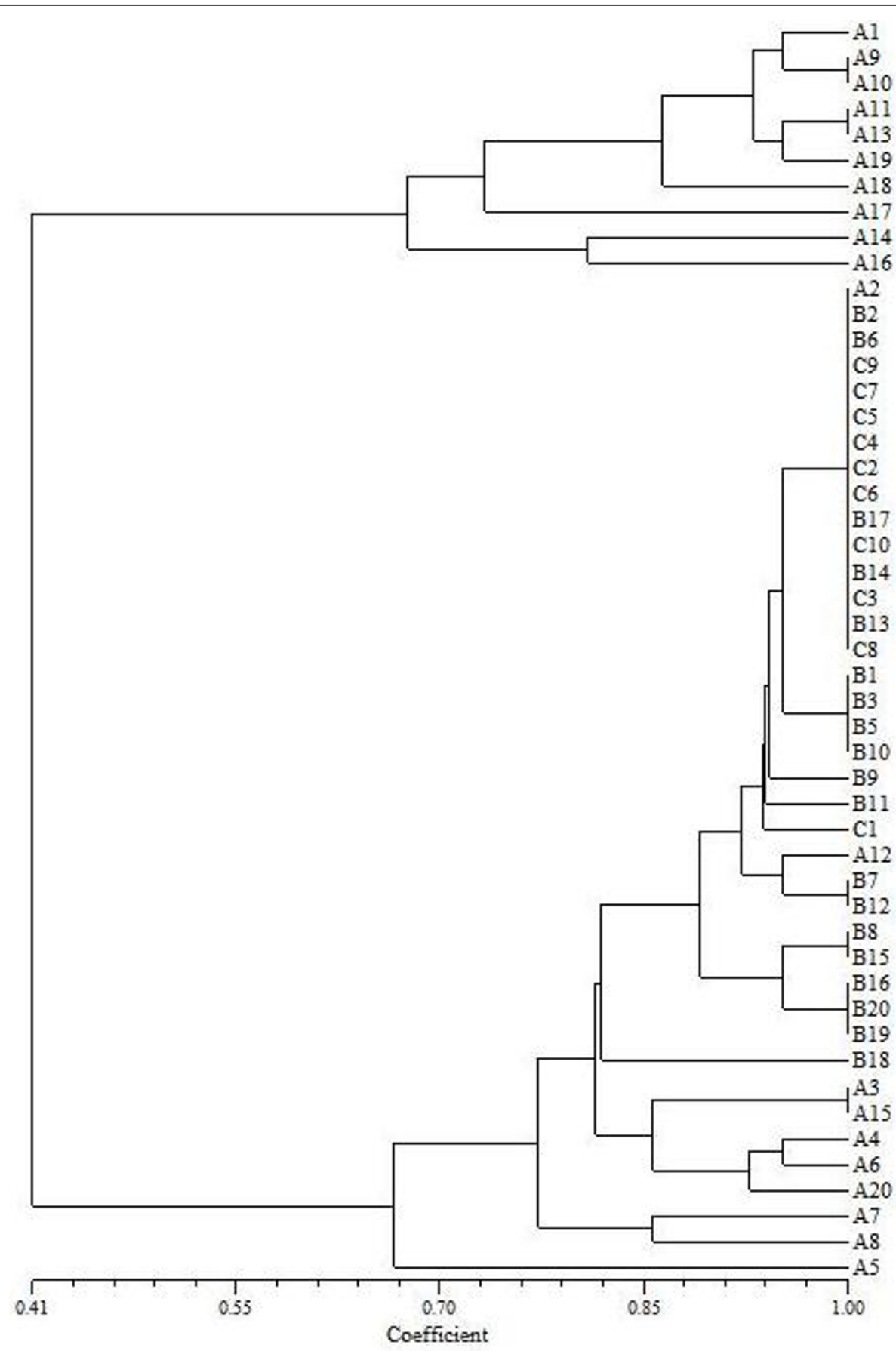

Figure 4 Similarity of cultured microorganisms from La Sal del Rey based on phenotype profiles. A total of 21 different enzymatic reactions were assayed using API $20 \mathrm{E}^{\circledR}$ strips. Based on the number of positive tests and which of the 21 tests were positive, a phenotype profile was created and compared to the profile of all other tested isolates. The similarity coefficient is shown at the bottom.

and again we observed a trend that the communities from samples with lower salinity could use a greater number of substrates compared to communities from samples with high salinities. Communities from water samples tended to have greater substrate utilization, both in terms of number of utilized substrates and total activity, than communities from soil samples. This was despite the typically higher cfu density in soil samples compared to water samples.

In addition to the high densities of organisms we were able to cultivate and the high percentage of carbon utilization exhibited by the community as a whole, the 
Table 3 Putative identification of isolated bacteria from La Sal de Rey, Texas, USA.

\begin{tabular}{|c|c|c|c|}
\hline $\begin{array}{l}\text { Isolate } \\
\text { No. } \\
\end{array}$ & Closest Species & $\begin{array}{l}\text { Identity } \\
(\%)\end{array}$ & $\begin{array}{l}\text { Confidence } \\
\text { Level }\end{array}$ \\
\hline $\mathrm{A} 1$ & Bacillus fastidiosis & 95.3 & Genus \\
\hline$A 2 Y$ & Bacillus flexus & 87.4 & No match \\
\hline$A 2 D$ & Bacillus oleronius & 96.1 & Genus \\
\hline A3 & Bacillus oleronius & 95.8 & Genus \\
\hline A4 & Pseudomonas fulva & 98 & Genus \\
\hline A7 & Bacillus megaterium & 99.9 & Species \\
\hline A8 & $\begin{array}{l}\text { Exiguobacterium } \\
\text { acetylicum }\end{array}$ & 92.1 & No match \\
\hline A9 & Bacillus oleronius & 95.3 & Genus \\
\hline $\mathrm{A} 10$ & Pseudomonas fulva & 98 & Genus \\
\hline A11R & Halomonas aquamarina & 99.2 & Species \\
\hline $\mathrm{A} 12$ & Bacillus oleronius & 95.3 & Genus \\
\hline A13W & Bacillus thuringiensis & 99.9 & Species \\
\hline A13Y & Bacillus horikoshii & 99.1 & Species \\
\hline A14 & $\begin{array}{l}\text { Exiguobacterium } \\
\text { acetylicum }\end{array}$ & 92.1 & No match \\
\hline A15 & Bacillus firmus & 97.8 & Genus \\
\hline A16 & Bacillus oleronius & 95.3 & Genus \\
\hline A17 & $\begin{array}{l}\text { Exiguobacterium } \\
\text { acetylicum }\end{array}$ & 92.1 & No match \\
\hline A18 & Halomonas aquamarina & 99.1 & Species \\
\hline A19 & Planococcus citreus & 99.1 & Species \\
\hline A20 & $\begin{array}{l}\text { Exiguobacterium } \\
\text { acetylicum }\end{array}$ & 92.1 & No match \\
\hline B1 & Bacillus circulans & 65.4 & Genus \\
\hline B2 & Bacillus firmus & 97.8 & Genus \\
\hline B3 & Vibrio alginolyticus & 97.8 & Genus \\
\hline B5R & Halomonas aquamarina & 98.7 & Genus \\
\hline B17 & $\begin{array}{l}\text { Paenibacillus } \\
\text { curdlanolyticus }\end{array}$ & 87.4 & No match \\
\hline B18 & Vibrio alginolyticus & 98.1 & Genus \\
\hline C1 & Bacillus firmus & 97.7 & Genus \\
\hline C2 & Bacillus firmus & 97.7 & Genus \\
\hline C3 & Bacillus firmus & 97.7 & Genus \\
\hline C4 & Bacillus firmus & 97.7 & Genus \\
\hline C5 & Bacillus firmus & 97.8 & Genus \\
\hline C6 & Bacillus firmus & 97.8 & Genus \\
\hline C7 & Bacillus firmus & 97.8 & Genus \\
\hline C8 & Bacillus firmus & 97.8 & Genus \\
\hline C9 & Bacillus firmus & 97.8 & Genus \\
\hline $\mathrm{C} 10$ & Bacillus firmus & 97.8 & Genus \\
\hline D12 & Bacillus oleronius & 95.8 & Genus \\
\hline
\end{tabular}

individual organisms we tested displayed a range of biochemical phenotypes when tested with API $20 \mathrm{E}^{\circledR}$ strips. API $20 E^{\circledR}$ strips were designed for rapid identification of clinical organisms, especially enteric bacteria. However, many of the tests on the strip are based on traditional microbiological selective and differential media formulations or enzymatic tests. We used API $20 \mathrm{E}^{\circledR}$ strips in an ecological sense in order to take the place of the traditional methods and rapidly construct a phenotype profile for the isolated organisms. The similarity dendogram that resulted from the API $20 \mathrm{E}^{\circledR}$ profiles showed that although some organisms were highly similar or even 100\% similar, 35\% (17/49) had a unique phenotype profile. Hedi et al. [13] also used API $20 \mathrm{E}^{\circledR}$ strips to characterize halophilic bacteria from a salt lake in Tunisia and observed similar results. Most of the isolates in that study were highly or $100 \%$ similar but several showed unique biochemical profiles compared to other organisms.

Hollister et al. [28] and Swan et al. [6] found high percentages of Proteobacteria in their phylogenetic analyses of La Sal del Rey and a salt lake in California, respectively. Members of the Proteobacteria are all gram-negative organisms and one subdivision in the phylum, the Gammaproteobacteria, are all rod-shaped organisms. Other studies of halophiles isolated from various habitats routinely describe gram-negative bacteria, including members of the Proteobacteria [7-9,14,32]. However, Proteobacteria are not usually the dominant phylum in hypersaline environments. Halophilic gram-positive bacteria [3], including spore-forming strains $[2,13]$, are common. Furthermore, in some hypersaline systems Archaea dominate over Bacteria [6]. Thus, although gram-negative Proteobacteria were the dominant bacteria detected in a previous study of La Sal del Rey [28], other phyla were more easily cultured especially at lower salinities. However, this may not be the case if the experiments were repeated using buffers and media with higher salinities.

Our study suggests that molecular signatures such as those acquired for the La Sal del Rey previously [28], do not always correspond to the culturing capability of organisms from the site. Of the organisms we isolated in pure culture, most of the $16 \mathrm{~S}$ rDNA sequences matched most closely to gram-positive genera (Table 2). This included partial matches to several species of Bacillus and Exiguobacterium. Surprisingly, some of these isolates were observed to be gram-negative rods when viewed with traditional gram staining. This initially led us to conclude that these organisms were most likely Proteobacteria. For example, isolates A9 and D12 both stained gram-negative (data not shown); however, $16 \mathrm{~S}$ rDNA sequencing matched these organisms most closely to Bacillus oleronius. Kuhnigk et al. [33] isolated B. oleronius from the hindgut of termites and also observed that it stained gram-negative although chemical and phylogenetic assays grouped the organism with the genus Bacillus. The authors further observed that the isolated $B$. oleronius had a strong resemblance to other members of the genus, especially the $B$. firmus- $B$. lentus group [33]. Many of our isolates, especially those from site $C$, matched closely to $B$. firmus, but in many cases 
our sequence data only matched to the genus level. Thus, the best determination we can make to-date is that these are unknown or poorly-described members of the genus Bacillus, are non-obligate halophiles, and are easily cultured from La Sal del Rey.

Many of the genera and species we identified were organisms typically found in soils, such as $B$. firmus, $B$. megaterium, and $B$. thuringeiensis. The latter, $B$. thuringiensis, produces insecticidal proteins and is used in transgenic crops and to control agricultural pests [34]. Weather events, such as tropical cyclones that occur in South Texas, may contribute to the introduction of microorganisms into La Sal del Rey that may not be indigenous. The sample isolates we sequenced were collected prior to the landfall of Hurricane Alex in summer 2010; therefore, the hurricane was not a contributing factor for our sequenced isolates. The presence of these typically low $\mathrm{G}+\mathrm{C}$ gram-positive soil organisms in La Sal del Rey many be due to runoff from nearby soils and fields. Inbakandan et al. [35] concluded that members of the genus Exiguobacterium found in marine environments probably have a terrestrial soil origin. Cultures of B. thuringiensis grown under hyperosmotic conditions display halotolerance [34]. Thus, many of the organisms we cultured are possibly just halotolerant and are not obligate halophiles.

Several isolated bacteria were identified as gram-negative Gammaproteobacteria (e.g., Vibrio alginolyticus and Halomonas aquamarina), which is in agreement with the culture-free studies of Hollister et al. [28]. Bacterium $V$. alginolyticus has been detected in marine and freshwaters environments and can tolerate a range of salinities [36]. Our laboratory recently identified a culture of $V$. alginolyticus from the Laguna Madre, a hypersaline estuary in South Texas, which could tolerate elevated concentrations of arsenic when grown in media supplemented with 30 ppt $\mathrm{NaCl}$ (Eubanks et al.: Genetic Characterization of Putative Arsenic-Oxidizing Bacteria Isolated from the Lower Laguna Madre of Texas, submitted). Halomonas aquamarina, also in the Gammaproteobacteria, has been described as a slight-tomoderate halophile that produces ectoine as the principle compatible solute and has been isolated from many marine environments including the Pacific Ocean, deepsea basins, Antarctica, and hypersaline lakes $[37,38]$. The genus Halomonas has a polyphyletic evolutionary lineage and contains at least 3 main evolutionary branches $[38,39]$. This may explain, in part, it wide ranging distribution.

A greater density of microorganisms was observed in La Sal del Rey soil samples versus water samples. This was not surprising as soils and sediments typically have greater microbial community sizes compared to water- borne communities. Despite this, the microbial communities from water samples showed on average higher total activities and a higher number of carbon sources utilized compared to their counterpart soil samples (ABC vs DEF, respectively). This we did not expect and further demonstrates the complex nature of the microbial community inhabiting La Sal del Rey.

\section{Conclusions}

La Sal del Rey is largely un-described with regards to the microbial ecology of the ecosystem. Traditional microbiological analysis, including culture experiments, carbon source utilization, biochemical profiling, and microscopy, along with $16 \mathrm{~S}$ rDNA sequencing supports the hypothesis that bacteria are common organisms in the microbial community of La Sal del Rey.

\section{Acknowledgements}

The authors wish to thank David Ramirez Jr., Jacqueline Valencia, Ibdanelo Cortez, and Thomas A. Eubanks for assistance with sample collection and data collection. We are grateful for suggestions of anonymous reviewers for improving the manuscript. This study was conducted as part of the South Texas Research Internships for the Development of Educators in Science (STRIDES) program at the University of Texas - Pan American and funded by the Howard Hughes Medical Institute (HHMI) Undergraduate Science Education Program (Grant \#520006321).

\section{Author details}

${ }^{1}$ Science Department, Riverside Middle School, San Benito, Texas USA

${ }^{2}$ Department of Biology, University of Texas - Pan American, Edinburg, Texas USA.

\section{Authors' contributions}

KP and FZ collected samples from La Sal del Rey on 14 June 2010. KP carried out the culture experiments, salinity measurements, EcoPlate ${ }^{T M}$ assays, and API 20E ${ }^{\circledast}$ assays. FZ participated in the design of the study, collected samples on 5 July 2010, performed all statistical analyses, and helped draft the manuscript. ORE cultivated and prepared the cultures for 165 rDNA sequencing and helped draft the manuscript. KLL conceived the study, assisted in the EcoPlate ${ }^{T M}$ assays, analyzed data, and drafted the manuscript. All authors read and approved the final manuscript.

\section{Competing interests}

The authors declare that they have no competing interests.

Received: 28 October 2010 Accepted: 2 February 2012

Published: 2 February 2012

\section{References}

1. Bardavid RE, Ionescu D, Oren A, Rainey FA, Hollen BJ, Bagaley DR, Small AM, McKay C: Selective enrichment, isolation and molecular detection of Salinibacter and related extremely halophilic Bacteria from hypersaline environments. Hydrobiologia 2007, 576:3-13.

2. Hua NP, Kanekiyo A, Fujikura K, Yasuda H, Naganuma T: Halobacillus profundi sp. nov. and Halobacillus kuroshimensis sp. no., moderately halophilic bacteria from a deep-sea methane cold seep. Int J Syst Evol Microbiol 2007, 57:1243-1249.

3. Hezayen FF, Younis MAM, Hagaggi NSA, Shabeb MSA: Oceanobacillus aswanensis strain FS10 sp. nov., an extremely halotolerant bacterium isolated from salted fish sauce in Aswan City, Egypt. Global J Mol Sci 2010, 5:1-6.

4. Chen YG, Cui XL, Pukall R, Li HM, Yang YL, Xu LH, Wen ML, Peng Q, Jiang CL: Salinicoccus kunmingensis sp. nov., a moderately halophilic bacterium isolated from a salt mine in Yunnan, south-west China. Int J Syst Evol Microbiol 2007, 57:2327-2332. 
5. Xiang W, Guo J, Feng W, Huang M, Chen H, Zhao J, Zhang J, Yang Z, Sun Q: Community of extremely halophilic bacteria in historic Dagong Brine Well in southwestern China. World J Microbiol Biotechnol 2008, 24:2297-2305.

6. Swan BK, Ehrhardt CJ, Reifel KM, Moreno LI, Valentine DL: Archaeal and bacterial communities respond differently to environmental gradients in anoxic sediments of a California hypersaline lake, the Salton Sea. Appl Environ Microbiol 2010, 76:757-768.

7. Sorokin DY, Tourova TP, Galinski EA, Bellach C, Tindall B: Extremely halophilic denitrifying bacteria from hypersaline inland lakes, Halovibrio denitrificans sp. nov. and Halospina denitrificans gen. nov., sp. nov., and evidence that the genus name Halovibrio Fendich 1989 with the type species Halovibrio variabilis should be associated with DSM 3050. Int J Syst Evol Microbiol 2006, 56:379-388.

8. Xu XW, Wu YH, Zhao Z, Wang CS, Zhou YG, Zhang HB, Wang Y, Wu M: Halomonas saccharevitans sp. nov., Halomonas arcis sp. nov. and Halomonas subterranean sp. nov., halophilic bacteria isolated from hypersaline environments of China. Int J Syst Evol Microbiol 2007, 57:1619-1624

9. Mondino $L$, Asao M, Madigan MT: Cold-active halophilic bacteria from the ice-sealed Lake Vida, Antarctica. Arch Microbiol 2009, 191:785-790.

10. Oren A: Microbial life at high salt concentrations: phylogenetic and metabolic diversity. Saline Systems 2008, 4:2, 13 p.

11. DasSarma S, DasSarma P: Halophiles. elS 2006.

12. Bowers K, Mesbah NM, Wiegel J: Biodiversity of poly-extremophilic Bacteria: does combining the extremes of high salt, alkaline $\mathrm{pH}$ and elevated temperature approach a physic-chemical boundary for life? Saline Systems 2009, 5:9.

13. Hedi A, Sadfi N, Fardeau ML, Rebib H, Cayol JL, Ollivier B, Boudabous A: Studies on the biodiversity of halophilic microorganisms isolated from El-Djerid Salt Lake (Tunisia) under aerobic conditions. Int J Microbiol 2009, 2009(Article ID 731786):17.

14. López-López A, Yarza P, Richter M, Suárez-Suárez A, Antón J, Niemann H, Roselló-Móra R: Extremely halophilic microbial communities in anaerobic sediments from a solar saltern. Environ Microbiol Rep 2010, 2:258-271.

15. Sánchez-Román M, Rivadeneyra MA, Vasconcelos C, McKenzie JA: Biomineralization of carbonate and phosphate by moderately halophilic bacteria. FEMS Microbiol Ecol 2007, 61:273-284.

16. Le Borgne S, Paniagua D, Vazquez-Duhalt : Biodegradation of organic pollutants by halophilic bacteria and archaea. J Mol Microbiol Biotechnol 2008, 15:74-92

17. Oncescu T, Oancea P, Enache M, Popescu G, Dumitru L, Kamekura M: Halophilic bacteria are able to decontaminate dichlorvos, a pesticide, from saline environments. Cent Eur J Biol 2007, 2:563-573.

18. Al-Mailem DM, Sorkhoh NA, Al-Awadhi H, Eliyas M, Radwan SS: Biodegradation of crude oil and pure hydrocarbons by extreme halophilic Archaea from hypersaline coasts of the Arabian Sea. Extremophiles 2010, 14:321-328.

19. Zhao B, Wang H, Mao X, Li R: Biodegradation of phenanthrene by halophilic bacterial consortium under aerobic conditions. Curr Microbiol 2009, 58:205-210.

20. Chen L, Wang G, Bu T, Zhang Y, Wang Y, Liu M, Lin X: Phylogenetic analysis and screening of antimicrobial and cytotoxic activities of moderately halophilic bacteria isolated from the Weihai Solar Saltern (China). World J Microbiol Biotechnol 2010, 26:879-888.

21. Sadfi-Zouaoui N, Essghaier B, Hhajlaoui MR, Fardeau ML, Cayaol JL, Ollivier B, Boudabous A: Ability of moderately halophilic bacteria to control grey mould disease on tomato fruits. J Phytopathology 2008 156:42-52.

22. Billi D, Potts M: Life and death of dried prokaryotes. Res Microbiol 153:7-12.

23. Schuldiner S, Fishkes $\mathrm{H}$ : Sodium-proton antiport in isolated membrane vesicles of Escherichia coli. Biochem 1978, 17:706-711.

24. Hamaide F, Kushner DJ, Sprott GD: Proton motive force and $\mathrm{Na}+\mathrm{H}+$ antiport in a moderate halophiles. J Bacterio/ 1983, 156:537-544.

25. United States Fish and Wildlife Service. [http://www.fws.gov/southwest/ refuges/texas/STRC/Irgv/index_LRGV.html]

26. Texas Beyond History. [http://www.texasbeyondhistory.net/st-plains/ images/he5.html].

27. Hart JP: Oil, the courts, and the railroad commission. Southwest Hist Quar 1941, 44:303-320.
28. Hollister EB, Engledow AS, Hammett AJM, Provin TL, Wilkinson HH, Gentry TJ: Shifts in microbial community structure along an ecological gradient of hypersaline soils and sediments. ISME J 2010, 4:829-838.

29. SAS Institute: SAS Users Guide: Statistics, Version 5 Cary: SAS Institute, Inc; 1985.

30. Zar JH: Biostatistical Analysis, Second Edition Englewood Cliffs: Prentice Hall; 1984.

31. National Oceanic and Atmospheric Administration. [http://www.srh.noaa gov/crp/?n=hurricanealex].

32. Maturrano L, Valens-Vadell M, Rosselló-Mora R, Antón J: Salicola marasensis gen. nov., sp. nov., an extremely halophilic bacterium isolated from the Maras solar salterns in Peru. Int J Syst Evol Microbiol 2006, 56:1685-1691.

33. Kuhnigk T, Borst EM, Breunig A, König H, Collins MD, Hutson RA, Kämpfer P: Bacillus oleronius sp.nov., a member of the hindgut flora of the termite Reticulitermes santonensis (Feytaud). Can J Microbiol 1995, 41:699-706.

34. Sachidanandham R, Al-Shayji Y, Al-Awadhi N, Yew-Hoong Gin K: A cryptic Bacillus isolate exhibited narrow16S rRNA gene sequence divergence with Bacillus thuringiensis and showed low maintenance requirements in hyper-osmotic complex substrate cultivations. Biotechnol Bioeng 2005, 91:838-847.

35. Inbakandan D, Murthy PS, Venkatesan R, Khan SA: 16S rDNA sequence analysis of culturable marine biofilm forming bacteria from a ship's hull. Biofouling 2010, 26:893-899.

36. Schets FM, van den Berg HH, Marchese A, Garbom S, de Roda Husman AM: Potentially human pathogenic vibrios in marine and fresh bathing waters related to environmental conditions and disease outcome. Int $J$ Hyg Environ Health 2011.

37. Sass AM, Sass H, Coolen MJ, Cypionka H, Overmann J: Microbial communities in the chemocline of a hypersaline deep-sea basin (Urania basin, Mediterranean Sea). Appl Environ Microbiol 2001, 67:5392-5402.

38. Brenner DJ, Krieg NR, Staley JT: Bergey's Manual of Systematic Bacteriology, Second Edition, Volume Two: The Proteobacteria, Part B The Gammaproteobacteria New York: Springer; 2005.

39. de la Haba RR, Arahal DR, Marquez MC, Ventosa A: Phylogenetic relationships within the family Halomonadaceae based on comparative 23S and 16S rRNA gene sequence analysis. Int J Syst Evol Microbiol 2010, 60:737-748.

doi:10.1186/2046-9063-8-5

Cite this article as: Phillips et al:: Phenotypic characterization and $16 \mathrm{~S}$ rDNA identification of culturable non-obligate halophilic bacterial communities from a hypersaline lake, La Sal del Rey, in extreme South Texas (USA). Aquatic Biosystems 2012 8:5.

\section{Submit your next manuscript to BioMed Central and take full advantage of:}

- Convenient online submission

- Thorough peer review

- No space constraints or color figure charges

- Immediate publication on acceptance

- Inclusion in PubMed, CAS, Scopus and Google Scholar

- Research which is freely available for redistribution

Submit your manuscript at www.biomedcentral.com/submit
C Biomed Central 